DOI 10.37882/2223-2974.2021.02.10

\title{
К ВОПРОСУ О МЕРАХ ГОСУДАРСТВЕННОЙ ПОДДЕРЖКИ НАСЕЛЕНИЯ И БИЗНЕСА В НЕКОТОРЫХ ЗАРУБЕЖНЫХ ГОСУДАРСТВАХ В ПЕРИОД ПАНДЕМИИ
}

\section{ON THE ISSUE OF MEASURES OF STATE SUPPORT FOR THE POPULATION AND BUSINESS IN SOME FOREIGN COUNTRIES DURING THE PANDEMIC \\ N. Kuznetsova \\ T. Matveeva}

Summary: The authors of the article analyzed the measures of state support and assistance during the coronacrisis in certain European countries: Italy, Germany, Great Britain. The authors analyze the policy of states to take anti-crisis measures and support the population and economy. The conclusions reached by the authors of the article show that the same problems that have befallen each state are solved differently by countries, but they are all aimed at fighting the coronavirus.

Keywords: state support, legal policy, social protection, anti-crisis measures, pandemic, coronavirus, government assistance.

\author{
Кузнецова Наталья Александровна \\ старший преподаватель, ФКОУ ВО «Владимирский \\ юридический институт ФСИН России» \\ kuz1503@yandex.ru \\ Матвеева Тамара Павловна \\ старший преподаватель, ФКОУ ВО «Владимирский \\ юридический институт ФСИН России» \\ matveeva33@mail.ru
}

Аннотация: Авторы в статье провели анализ мер государственной поддержки и помощи в период коронакризиса в отдельных европейских государствах: Италия, Германия, Великобритания. Авторами анализируется политика государств по принятию антикризисных мер и поддержки населения и экономики. Выводы, к которым пришли авторы статьи, показывают, что одинаковые проблемы, обрушившиеся на каждое государство, странами решаются по-разному, но все они направлены на борьбу с коронавирусом.

Ключевые слова: государственная поддержка, правовая политика, социальная защита, антикризисные меры, пандемия, коронавирус, правительственная помощь.

циальной политике. Проблемы, обрушившиеся на мир в период пандемии, заставили многие государства срочно предпринимать необходимые меры для поддержки населения, бизнеса, разработать программы поддержки экономики в целом.

Каждая страна по своему осуществляла и осуществляет до настоящего времени борьбу с неизвестной до сегодняшнего дня инфекцией. Некоторые страны долго не осознавали всю трагедию, случившуюся в мире, и не были готовы к последствиям, постигшим практически всех. Лишь Китай, быстро среагировал и не дал масштабного распространения инфекции, которая именно в данной стране была выявлена, и сумел восстановить работу.

Мы же постараемся рассмотреть, возникшие в период кризиса проблемы некоторых зарубежных стран и найти пути их решения.

Во всех странах в эпицентре коронавируса оказались в первую очередь медики. И в действительности получилось, что страны не были готовы к большому количеству заболевших, а медицинский персонал не справлялся с потоком ковидных больных. Очаги инфекции возникали повсюду: в больницах, в домах престарелых, куда поступали зараженные инфекцией люди. Система здравоохранения многих стран оказалось перегружена, осо- 
бенно это проявилось в Соединенных Штатах Америки, Италии, Германии, Испании, Китае.

Как же отреагировали государства чтобы, защитить своих граждан от последствий коронавирусной инфекции.

В европейских странах, которые ранее сталкивались с кризисом, стали предпринимать антикризисные меры, разрабатывая различные программы в поддержку наиболее пострадавших отраслей, выделив миллиарды в помощь населению, бизнесу, здравоохранению, справляясь с последствиями еще не остановленной пандемии.

Италия, как и другие европейские страны, ощутила на себе коронавирусную инфекцию. Она была первой европейской страной, ощутившей последствия нового вируса. Как и повсюду удар пришелся на здравоохранение, население, экономику. Указ, принятый в марте 2020 года был экстренной экономической помощью для бизнеса и населения. Почти 120 статей Указа определяли действия правительства по поддержке семей с детьми, самозанятых и фрилансеров, наемных работников.

Как в любой стране борьбу с коронавирусной инфекцией осуществили первыми медицинские работники. В правительственных мерах по поддержке населения и бизнеса в Италии медикам, которые непосредственно работами с больными была выплачена единовременная премия в размере тысячи евро, кроме этого для поддержки семей медицинских работников предусматриваются выплаты в размере до 2 тысяч евро ежемесячно. Общая сумма финансовой помощи на поддержку населения и бизнеса итальянским правительством определялась в 55 млрд. евро. Так, меры государственной поддержки в Италии были направлены на здравоохранение - более 3,5 млрд. евро, 25 млрд. евро решено было выделить на поддержку семей, которые оказались в трудной жизненной ситуации из-за самоизоляции и закрытии предприятий, также на поддержку малых предприятий. 1, 5 млрд. евро было выделено в Фонд чрезвычайных ситуаций в стране, созданный службой гражданской защиты. Лимит Фонда определялся в 300 миллионов евро. Итальянские школы, чтобы остановить распространение вируса были закрыты первыми и не торопились их открывать. Родителям, которые продолжали работать, не смотря на карантинные меры, компенсировались услуги няни (специальный ваучер в размере 600 евро, в последствие данная сумма была увеличена до 1,5 тысячи евро). Также компенсировались отпуска родителям, которые вынуждены были оставаться с детьми до 50\% надбавки. Семьям, где семейный доход ниже 40 тыс. евро в год государство предоставило премию 100 евро. Данный бонус был предусмотрен государственным и частным служащим, которые продолжали работу на рабочих местах. Работникам, работающим в сельском хозяйстве, в туристической индустрии, сезонным работникам также предусматривалась выплата заработной платы государством из Фонда гарантирования выплаты заработной платы. Данная выплата осуществлялась сроком до 9 недель. [3]

Были приостановлены ипотечные выплаты по кредитам для самозанятых и граждан, которые оказались без работы из-за прекращения действия предприятий. В период карантинных мер на работников оформлялся больничный лист. Индивидуальные предприниматели, самозанятые, если они не получают пенсию могли рассчитывать на единовременную компенсацию в размере 500 евро. Для этого в стране был создан фонд с размером 200 миллионов евро. Наиболее пострадавшие компании, которые приостановили свою деятельность, такие как образовательные учреждения, спортивные, туристические, компании общественного питания и другие могли воспользоваться правом на приостановку налогов и других платежей без штрафных санкций.

Таким образом, итальянское правительство постаралось оказать помощь своему населению и поддержать экономику. Эффективными оказались действия государства по принятию пакетов антикризисных мер. Но коронавирус еще не побежден и борьба с ним продолжается.

Следующей страной, пострадавшей от коронавируса можно рассмотреть Великобританию. Большое количество заболевших, как и в других странах произошло изза запоздалой реакции британского правительства на смертоносную инфекцию. Ситуация в стране до сих пор остается тяжелейшей. Национальная служба здравоохранения, как и в других странах, столкнулась огромной нагрузкой. Это повлекло отчаянные попытки медиков справиться с ситуацией до введения карантинных мер. Нехватка медицинских работников, койко- мест и медикаментов открывает проблемы в здравоохранении Соединенного Королевства, да и не только там. Многие государства не были готовы к такому стремительному развитию событий, связанных с распространением инфекции. До настоящего времени в Британии высок уровень смертности от COVID-19. Национальная служба здравоохранения, как и в первую волну кризиса, сталкивается с множеством проблем. Недостаточно медицинского оборудования, медикаментов, медицинских работников, чтобы справиться с нарастающим потоком больных.

Возросший уровень безработицы, закрытие предприятий, сокращение рабочих мест, снижение потребительской способности населения, вынужденные отпуска потребовали от британского правительства координальных мер поддержки.

Финансовая помощь британского правительства с начала распространения COVID-19 была оказана около 
1 миллиона предприятиям. Для компаний были предложены кредитные гарантии на 330 миллиардов фунтов стерлингов, обеспеченные государственной гарантией, физическим и юридическим лицам, у которых имелись ссуды и ввиду кризиса они не могли их погашать во время карантина были предложены кредитные каникулы.

Во время второй волны коронавируса данные выплаты работникам, отправленным в вынужденные отпуска, были продлены. По данным бюро Национальной статистики в первый период пандемии с марта по июнь 2020 года число работников ведомственных предприятий снизилось почти на 750 тысяч. Чтобы снизить безработицу и восстановить экономику страны правительство ввело неполную занятость. Разработанные правительством программы определяли компенсации работникам, пострадавших компаний до 80\% выплат от заработной платы, если они не превышают 2,5 тысяч фунтов стерлингов в месяц, чтобы избежать увольнений. Это правительственные гранты на выплату зарплат. [4]

Гостиничный, туристический бизнес, малые предприятия торговли были освобождены на период пандемии от уплаты налога на коммерческую деятельность. Для тех, кто затруднен в средствах выплат по ипотеке была предоставлена 3-х месячная отсрочка. Чтобы спасти рабочие места и поддержать британскую экономику правительством были приняты меры по предоставлению налоговых льгот отелям, ресторанам. Для самозанятых британское правительство также предусмотрело определенные меры финансовой поддержки. Например, денежные выплаты не зависимо от снижения дохода.

Кроме всего принимаются и другие меры поддержки такие как увеличение адресных денежных трансферов, субсидирование заработной платы, нестраховые меры социальной защиты.

Несмотря на все меры поддержки, безработица в стране растет, а количество вакансий на предприятиях, которые возобновляют работу сравнительно мало, но канцлер казначейства Великобритании Риши Сунак уверен, что «у правительства есть четкий план по защите, поддержке и созданию рабочих мест, благодаря которому ни один гражданин не останется в безнадежном положении». [5]

На сегодня ситуация в Британии одна из самых тяжелых по заражению инфекцией. Поэтому большинство мер, вырабатываемых правительством, направлены на здравоохранение, на разработку вакцины и на поддержку экономики и населения. Государство не снижает меры поддержки для своего населения. Планируется снизить НДС да 5\% для компаний, которые больше всех пострадали из-за пандемии коронавируса. Кроме всего британское правительство выделило 9 млрд. фунтов на программу занятости и дополнительно 2 млрд. фунтов стерлингов на стимулирование занятости среди молодежи. Для поддержки бизнеса и домовладельцев в Британии уже выделено порядка 132,6 млрд. фунтов стерлингов.

Следующая страна, на которую хотелось обратить внимание это Германия. Как и другие страны, ФРГ также пришлось принимать серьезные меры поддержки, чтобы сохранить экономику страны и помочь своему народу. Борьба медиков с коронавирусной инфекцией, самоизоляция населения, обвал экономики, борьба с безработицей - эти и другие трудности не обошли стороной государство.

В период пандемии был принят пакет законодательных мер для поддержки населения. Эта поддержка коснулась здравоохранения, бизнеса, предприятий, которые не выдержали финансовых затрат и вынуждены были снижать заработные платы или производить увольнения сотрудников и др. Страна была вынуждена принять дополнительный бюджет чтобы оказывать помощь больницам и медицинским работникам, принявшим на себя первый удар от пандемии. Общая стоимость мер, которые предприняло правительство для поддержки экономики, определяется в сумму 1,3 трлн. евро.[6]

Помощь работодателям осуществлялась в принятии особой финансовой поддержки. Федеральным правительством были увеличены госинвестиции на 12,4 млрд. евро, снижены требования для получения субсидий компаниями, в которых работников потребовалось перевести на неполный рабочий день. Было принято шесть законов, которые определяли смягчение последствий пандемии. Это прямые субсидии размером до 15 тыс. евро для малых предприятий и индивидуальных предпринимателей, поддержка самозанятых, государственная поддержка для больниц более 3 млрд. евро, финансовая поддержка поставщиков социальных услуг и учреждений социального обеспечения, медучреждений и медицинского персонала, дополнительные выплаты социальных пособий семьям с детьми, инвалидам, пенсионерам, безработным. Была запущена специальная программа для бизнеса о возможности получения неограниченных кредитов. Для обеспечения граждан и их безопасности в условиях самоизоляции правительство Германии старалось создать все необходимые меры поддержки для обеспечения населения продуктами питания, обеспечить работу важных жизненных секторов, таких как здравоохранение, больницы, аптеки, сельское хозяйство.

Как и в любом государстве в Германии особая помощь оказывается детям. Она складывается из государственных пособий на детей независимо от возраста, из родительских выплат, дополнительных выплат для по- 
купки школьных принадлежностей, помощь работающим и малоимущим родителям и другие виды поддержки. Например, в период кризиса, связанного с COVID-19 в Германии семьям с детьми государство предусмотрело выплатить по 300 евро на каждого ребенка, но данными выплатами в полном объеме смогут воспользоваться не все семьи. Условие выплаты предусматривало получение хотя бы первой суммы в течение одного осеннего месяца, а вот далее, если семья имеет высокий доход и получает в полном объеме весь Kinderbonus, то в последствие она должна будет вернуть эти деньги полностью или внести их по частям в виде налога. Данная выплата семьям с детьми в Германии явилась стимулом в условиях кризиса, но правительство в тоже время старалось хотя бы таким способом простимулировать покупательский спрос и поддержать экономику.

Кроме всего в Германии достаточно большое количество пособий, выплачиваемых родителям на детей, которые также были увеличены в период пандемии. Это детская добавка при уменьшении дохода родителей, компенсация потерянного заработка из-за ухода за ребенком и др. Семьи, получавшие до коронавирусного кризиса максимальные выплаты на детей, но потерявшие работу, ввиду чего доход снизился, получили право на одноразовое продление получения пособия дополнительно еще на шесть месяцев.

Рассмотрев социальную обстановку в отдельно взятых европейских государствах, связанную с рас- пространением новой коронавирусной инфекцией, мы приходим к выводу, что все государства в той или иной степени, столкнувшись с последствиями, вызванными вспышкой инфекции вынуждены были в срочном порядке принимать непростые, иногда беспрецедентные решения по защите как самого населения, так и экономики страны в целом. Чаще всего эти меры были направлены на поддержку населения и бизнеса, защиту семьи, детей, обеспечение занятости и снижение безработицы. Сохранение рабочих мест и субсидирование отдельных секторов экономики показывает, что развитые страны в большей степени опираются на уже существующие меры поддержки в государстве, которые принимались в предыдущие финансовые кризисы. Вводя карантинные меры правительства государств, старались защитить своих граждан от COVID-19 и в тоже время выплата пособий, субсидий, кредитов помогла продержаться бизнесу. Но следует отметить, что коронакризис выявил и слабые места в государствах, например, в здравоохранении. Некоторым государствам, например, Китаю удалось относительно быстро справиться с пандемией, другие, например Германия, Великобритания продолжают борьбу и подбирают спасительные меры профилактики распространения инфекции и поддержки своих граждан.

Отсюда, следует отметить, что ситуации, в которых оказались государства и их экономика практически одинаковые, а вот принятые антикризисные мероприятия у каждой страны свои.

\section{ЛИТЕРАТУРА}

1. Экономика Великобритании: современное состояние и перспективы // https://zagranportal.ru/

2. Социальные последствия пандемии COVID-19 и инклюзивность. Дайджест подготовлен Департаментом международного и регионального сотрудничества // https://ach.gov.ru/upload/pdf/Covid-19-inclusion.pdf

3. Василий Жарков. Новый век начинается в 2020-м //https://www.gazeta.ru/

4. https://tass.ru/obschestvo/8470725

5. https://data.Iondon.gov.uk/publisher/ons

6. https://news.myseldon.com/ru/news/index/226168142

7. https://www.interfax.ru/world/711751

○ Кузнецова Наталья Александровна (kuz1503@yandex.ru), Матвеева Тамара Павловна (matveeva33@mail.ru).

Журнал «Современная наука: актуальные проблемы теории и практики» 